\title{
KONSTRUKSI KODE CROSS BIFIX BEBAS TERNAIR BERPANJANG GENAP UNTUK MENGATASI MASALAH SINKRONISASI FRAME
}

\author{
Moh. Affaf ${ }^{1}$, Zaiful Ulum ${ }^{2}$ \\ 1,2STKIP PGRI Bangkalan, mohaffaf@ stkippgri-bkl.ac.id, zaifululum @stkippgri-bkl.ac.id
}

\begin{abstract}
In order to guarantee the synchronization between a transmited data by transmitter and received data by receiver can be done by periodically inserting a fixed sequence into the transmited data. It is one of the main topic in digital communication systems which called Frame Synchronization. Study of Cross Bifix Free Codes arise to solve Synchronization's problem via distributed sequence's method which introducted by Wigngardeen and Willink in 2000. A Cross Bifix Free Codes is a set of sequences in which no prefix of any length of less than to $n$ of any sequences is the sufix of any sequence in the set. In 2012, Bilotta et al construct binary cross bifix free codes by using Dyck path. In 2017, Affaf et al was construct cross bifix free codes, $\operatorname{CBFS}_{3}(2 m+1)$, by generalize Bilotta's construction. In this paper, will be constructed Ternary Cross Bifix Free Codes for even length, $\mathrm{CBFS}_{3}(2 m+2)$, by using Bilotta and Affaf's construction.
\end{abstract}

Keywords: Cross Bifix Free Codes, Distributed sequence, Dyck path, Frame Synchronization.

\section{PENDAHULUAN}

Frame Synchronization adalah salah satu masalah dalam sistem komunikasi. Dalam sistem ini, untuk menjamin adanya keselarasan diantara transmitter/pengirim dan receiver/penerima pada frame data yang dipancarkan, disisipkan kata penyelaras secara periodik ke dalam aliran data. Untuk itu, penerima perlu mengetahui dimana aliran data dimulai. Dalam hal ini, kata penyelaras berperan sebagai penanda pada frame yang mana permulaan data dari pesan yang dikirimkan. 
Dalam kasus sinkronisasi ini, receiver dilengkapi dengan alat pendeteksi pola untuk mengenali kata penyelaras. Massey [1] mengajukan suatu prosedur untuk mencari kata penyelaras dalam suatu aliran data pada Gaussian Channel. Setahun kemudian, yakni di tahun 1973, Nielsen [2] menunjukkan bahwa pencarian kata penyelaras dapat diminimumkan jika kata penyelaras yang diambil memiliki sifat bebas imbuhan (bifix free). Disini terminologi Bifix Free diperkenalkan.

Pada tahun 2000 Wijngaarden dan Willink [3] memperkenalkan metode baru untuk mengatasi masalah Sinkronisasi frame. Caranya adalah dengan mengirimkan data-data yang berasal dari kode $\left\{x_{1}, x_{2} x_{3}, \ldots, x_{k}\right\}$ yang mempunyai sifat khusus. Agar permulaan dari suatu data frame dapat dikenali, kita harus memastikan bahwa semua akhiran sejati dari $x_{i}$ tidak muncul sebagai awalan dari $x_{j}$ untuk setiap $x_{i}$ dan $x_{j}$ anggota $\left\{x_{1}, x_{2} x_{3}, \ldots, x_{k}\right\}$. Kode yang seperti ini disebut Himpunan/Kode Cross Bifix Bebas. Selanjutnya, Bajic pada [4] dan [5] menjelaskan bagaimana sistem mencari,mendeteksi, dan menemukan barisan terdistribusi ini.

Peneliti mengusulkan beberapa cara untuk mengontruksi kode tersebut. Pertama Bajic [6], yang mengkontruksi kode tersebut dengan menggunakan metode yang disebut Kernel Set. Kemudian, pada 2012 Bilotta dkk [7] memperkenalkan kontruksi kode cross bifix bebas dengan panjang sebarang. Selanjutnnya, Affaf dan Ulum [8] memperluas konstruksi Bilotta untuk panjang ganjil sehingga menjadi Kode Cross Bifix Bebas Ternair.

Kontruksi kode cross bifix bebas dengan menggunakan alphabet yang mempunyai $q$ simbol diperkenalkan pertama kali di tahun 2013 oleh Chee [9]. Chee menamakan konstruksinya sebagai Kode $S_{k, q}(n)$, yaitu kode dengan $q$ simbol dimana $k$ menyatakan banyaknya simbol nol yang muncul pada awalan dengan panjang $n$ pada setiap katakode. Chee mengklaim bahwa kode yang dikonstruksinya mendekati kode optimal $C(n, q)$. Sayangnya keoptimalan kode Chee bergantung kepada parameter $k$. Tidak diketahui dengan pasti untuk panjang kode $n$ tertentu berapa nilai $k$ yang membuat $S_{k, q}(n)$ optimal.

Setahun kemudian, yaitu pada tahun 2015, Blackburn mengamati bahwa kode yang dihasilkan Chee memiliki sifat yang baik hanya saat $q$ simbol yang 
cukup kecil. Untuk mengatasi kelemahan tersebut, Blackburn mengajukan metoda baru yang merupakan perumuman dari metoda Chee yang mempunyai sifat yang baik untuk setiap parameter [10]. Blackburn mengklaim bahwa kode yang dihasilkannya optimal saat panjang katakodenya, yaitu $n$, membagi banyaknya simbol, yaitu $q$.

\section{METODE}

Pada bagian ini akan dijelaskan mengenai beberapa definisi dan istilah dalam teori koding yang terkait dengan kode cross bifix bebas. Selain itu, pada bagian ini juga diberikan definisi dan lintasan Grand Dyck dan lintasan Dyck yang merupakan ide utama dari konstruksi yang dilakukan oleh Bilotta. Di bagian akhir bagian ini akan diberikan metode konstruksi yang akan digunakan dalam penelitiaan ini.

\subsection{Definisi dan Istilah pada Kode}

Misalkan $\Sigma$ adalah himpunan berhingga dengan kardinalitas $q$. Anggota dari $\Sigma$ disebut simbol sedangkan $\Sigma$ disebut sebagai alfabet. Himpunan semua barisan berhingga (mungkin barisan kosong) di $\Sigma$ dinotasikan dengan $\Sigma^{*}$ dan anggota $\Sigma^{*}$ disebut kata atau katakode. Selanjutnya, katakan $\Sigma^{+}$adalah barisan berhingga yang takkosong di $\Sigma$. Dengan kata lain, $\Sigma^{+}=\Sigma^{*} \backslash\{\varepsilon\}$ dimana $\varepsilon$ menyatakan barisan kosong. Sebagai contoh, Misal $\Sigma=\{0,1\}$, maka $\varepsilon, 101$, 00011, 1110001 adalah anggota dari $\Sigma^{*}$, dimana $\varepsilon$ menyatakan barisan kosong, dengan $\varepsilon$ bukan anggota dari $\Sigma^{+}$.

Selanjutnya, untuk $\omega$ anggota $\Sigma^{+}$dengan $\omega=u v w$ dimana $u$ dan $w$ $\operatorname{anggota} \Sigma^{+}$serta $v$ anggota $\Sigma^{*}$, maka $u$ dan $w$ disebut prefix dan sufix dari $\omega$, dinotasikan berturut-turut sebagai $\operatorname{pre}(\omega)$ dan $\operatorname{suf}(\omega)$. Untuk prefix atau sufix dari $\omega$ dengan panjang $k$ dinotasikan dengan $\operatorname{pre}_{k}(\omega)$ atau $s u f_{k}(\omega)$, berurutan. Dari sini, jelas bahwa panjang sufix dan prefix suatu kata di $\Sigma^{+}$kurang dari panjang kata tersebut. Disini, didefinisikan pula $\left|\operatorname{pre}_{k}(\omega)\right|_{a}$ dan $\left|s u f_{k}(\omega)\right|_{a}$ berturut-turut sebagai banyaknya simbol $a$ pada prefix dan sufix dari $\omega$ dengan panjang $\mathrm{k}$. Contohnya, untuk $\Sigma=\{0,1\}$ dengan $\omega=111001001$, maka $\operatorname{pre}_{4}(\omega)$ adalah $1110, \operatorname{suf}_{3}(\omega)$ adalah 001, dan $\left|\operatorname{pre}_{5}(\omega)\right|_{0}$ adalah 2 . 
Sebuah bifix dari $\omega$ adalah sebuah kata yang muncul sekaligus sebagai prefix dan sufix dari $\omega$. Sebuah katakode di $\Sigma^{+}$disebut Bifix Bebas jika dan hanya jika tidak ada $\operatorname{pre}_{k}(\omega)$ yang sekaligus merupakan $s u f_{k}(\omega)$. Kemudian, subhimpunan dari $\Sigma^{+}$yang anggotanya kata-kata bifix bebas disebut himpunan bifix bebas. Lebih lanjut, subhimpunan tak kosong $C$ dari $\Sigma^{+}$disebut kode cross bifix bebas jika dan hanya jika untuk setiap $\omega_{i}$ dan $\omega_{j}$ di $C$ tidak ada $\operatorname{pre}_{k}\left(\omega_{i}\right)$ yang sekaligus $\operatorname{suf}_{k}\left(\omega_{j}\right)$. Jika $C$ subhimpunan dari $\Sigma^{\mathrm{n}}$, maka $C$ disebut kode cross bifix bebas dengan panjang $n$. Jelas bahwa kode cross bifix bebas adalah himpunan dari katakode bifix bebas. Sebagai contoh, untuk $\Sigma=\{0,1\}$, kata 1010101 di $\Sigma^{+}$memuat tiga bifix, yaitu 1, 101, dan 10101. Kemudian, himpunan katakode $\{1111000,111001100,1110100,1110010,1101010\}$ yang merupakan subhimpunan dari $\Sigma^{7}$ adalah kode cross bifix bebas dengan panjang 7 .

Pada subbagian selanjutnya, akan dibahas mengenai Lintasan Dyck, mengingat lintasan ini adalah ide utama dari konstruksi Bilotta. Sebelum itu, perlu diketahui tentang beberapa konsep lintasan yang akan mendukung definisi formal dari lintasan dyck.

\subsection{Lintasan Dyck}

Lintasan Latis dengan panjang $n$ ialah barisan koordinat $P_{0} P_{1} P_{2} \cdots P_{n}$ di $\mathbb{Z} \times \mathbb{Z}$ dengan $P_{j}$ dan $P_{j+1}$ dihubungkan oleh sebuah segmen/sisi untuk setiap $j=$ $0,1,2, \cdots n-1$. Untuk kemudahan, misalkan segmen yang menghubungkan $P_{j}$ dan $P_{j+1}$ dinotasikan dengan $P_{j} P_{j+1}$. Dengan kata lain, lintasan latis dengan panjang $n$ dapat dipandang sebagai lintasan pada koordinat kartesius yang setiap ujung segmennya berada pada koordinat bilangan bulat. Dalam hal representasi geometris, dapat dipandang $P_{0}=(0,0)$. Gambar 2.2.1 berikut ini adalah lintasan latis secara geometris dengan $n=7$. 


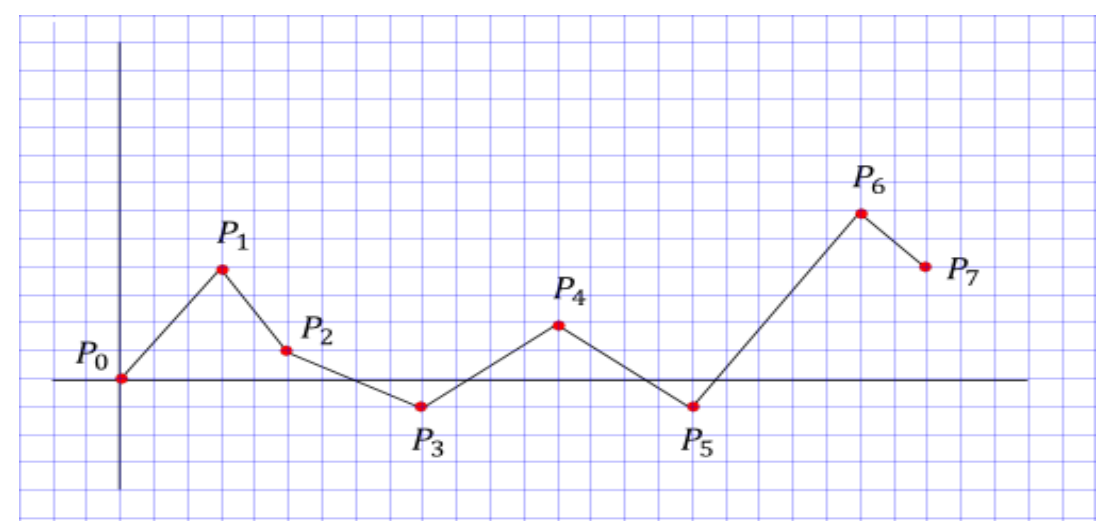

Gambar 2.2.1. Lintasan Latis dengan panjang 7

Selanjutnya, untuk $m>0$, lintasan latis dengan panjang $2 m, P_{0} P_{1} P_{2} \cdots P_{2 m}$, dikatakan Lintasan Grand Dyck jika dan hanya jika $P_{0}$ dan $P_{2 m}$ memiliki koordinat yang sama dan segmen $\mathrm{Pj} P \mathrm{P}+1$ termuat dalam garis bergradien 1 atau termuat dalam garis bergradien -1 serta $\left|P_{j} P_{j+1}\right|=\left|P_{k} P_{k+1}\right|$ untuk setiap $j$ dan $k$ di $\{0,1,2, \cdots n-1\}$. Untuk kemudahan bahasa, katakan segmen yang termuat pada garis bergradien 1 disebut langkah naik, dinotasikan dengan $x$ dan segmen yang termuat pada garis bergradien -1 disebut langkah turun, dinotasikan dengan $\bar{x}$. Dengan demikian, Lintasan Grand Dyck dengan panjang $2 m$ dapat didefinisikan sebagai lintasan yang berawal dari $(0,0)$ dan berakhir di $(2 m, 0)$ yang hanya memiliki langkah naik dan langkah turun, dimana setiap langkah tersebut memiliki panjang yang sama. Gambar 2.2.2 adalah lintasan Grand Dyck secara representasi geometris untuk $m=3$.

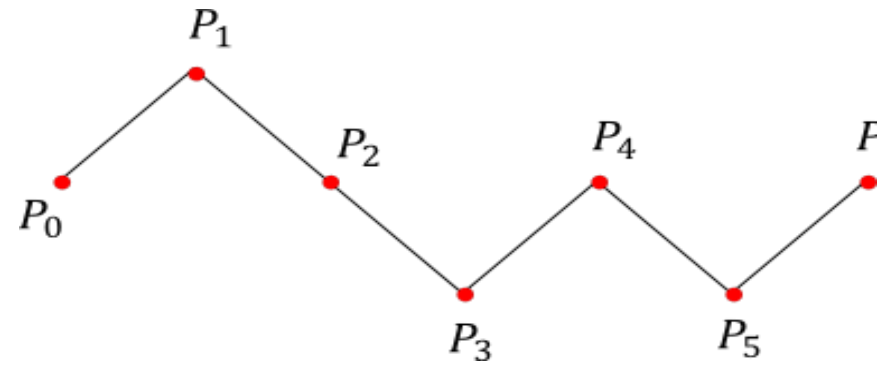

Gambar 2.2.2. Lintasan Grand Dyck dengan $m=3$

Lebih jauh, dengan asumsi $P_{0}=(0,0)$, maka lintasan Grand Dyck dengan panjang $2 m, P_{0} P_{1} P_{2} \cdots P_{2 m}$, dikatakan Lintasan Dyck dengan panjang $2 m$ jika dan hanya jika tidak ada $P_{i}$ berada yang berada di bawah sumbu- $x$. Gambar 2.2.3 berikut adalah Lintasan Dyck secara representasi geometris untuk $m=4$. 


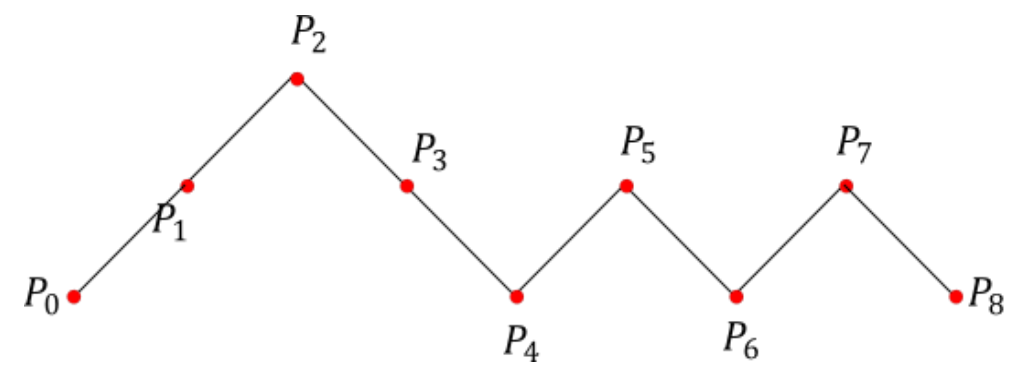

Gambar 2.2.3. Lintasan Dyck dengan $m=4$

Misalkan $D_{2 m}$ adalah himpunan lintasan Dyck dengan panjang $2 m$. Telah diketahui bahwa kardinalitas dari $D_{2 m}$ adalah sebanyak $\frac{1}{m+1}\left(\begin{array}{c}2 m \\ m\end{array}\right)$, yaitu Bilangan Catalan ke- $m$ yang dinotasikan dengan $C_{m}$. Salah satu bukti bahwa kardinalitas $D_{2 m}$ adalah bilangan Catalan ke- $m$ dapat dilihat pada paper yang ditulis Deutsch [11] pada tahun 1999. Lintasan Dyck dengan panjang nol didefinisikan sebagai lintasan latis yang hanya terdiri dari satu titik $\mathrm{P}$ di $\mathbb{Z} \times \mathbb{Z}$. Oleh karena itu, dikatakan kardinalitas dari $D_{0}$ adalah 1 .

Mengingat goal dari penelitian ini adalah memperluas Konstruksi Bilotta, maka kajian pustaka ini akan ditutup dengan konstruksi kode cross bifix bebas biner oleh Stefano Bilotta dkk pada tahun 2012. Bilotta mengkonstruksi kode cross bifix bebas biner dengan memanfaatkan lintasan Dyck. Dalam konstruksinya, Bilotta membagi kode yang dikonstruksinya menjadi tiga bagian, yaitu untuk panjang kode ganjil, panjang kode ganjil dengan parameter genap, dan panjang kode genap dengan parameter ganjil. Dari konstruksinya ini, Bilotta memperoleh hasil bahwa $\operatorname{CBFS}_{2}(n)$ adalah himpunan cross bifix bebas yang tak dapat diperluas di $H_{2}(n)$, yaitu himpunan kata kode biner dengan panjang $n$, artinya setiap diambil $h$ anggota $H_{2}(n)$ yang bukan anggota $\operatorname{CBFS}_{2}(n)$, maka himpunan $\mathrm{CBFS}_{2}(n) \backslash\{h\}$ bukan lagi himpunan cross bifix bebas.

\subsection{Konstruksi Kode Cross Bifix Bebas Biner oleh Bilotta}

Seperti yang telah dikatakan di atas, Bilotta membagi kode yang dikonstruksinya menjadi tiga bagian, yaitu untuk panjang kode ganjil, panjang kode ganjil dengan parameter genap, dan panjang kode genap dengan parameter ganjil. Oleh karena itu, subbagian ini akan dibagi lagi menjadi tiga bagian. 


\subsubsection{Konstruksi $\mathrm{CBFS}_{2}(2 m+1)$}

Kode cross bifix bebas $\mathrm{CBFS}_{2}(2 m+1)$ didefinisikan oleh Bilotta sebagai himpunan

$$
\operatorname{CBFS}_{2}(2 m+1)=\left\{x \alpha: \alpha \in D_{2 m}\right\},
$$

yaitu himpunan lintasan dengan panjang $2 m+1$ yang diawali dengan langkah naik yang kemudian diteruskan dengan lintasan Dyck dengan panjang $2 m$. Tentu saja, kardinalitas dari $\operatorname{CBFS}_{2}(2 m+1)$ adalah $C_{m}$, Bilangan Catalan ke- $m$. Gambar 2.3.1.2 berikut memberikan gambaran bagaimana Konstruksi Bilotta menghasilkan kode $C_{B F}(7)$, yaitu himpunan kata/katakode $\{1111000,1101100,1110010,1110100,1101010\}$.

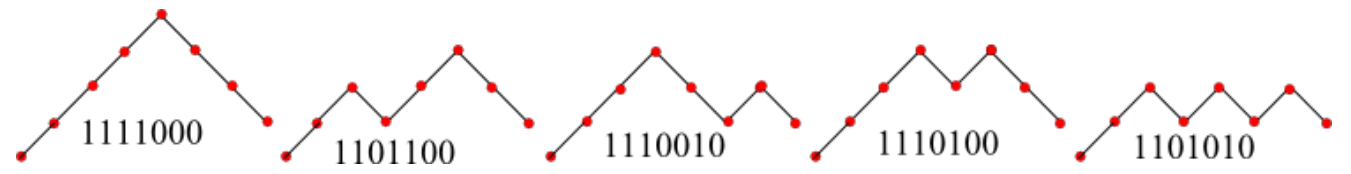

Gambar 2.3.1.1. Semua katakode di $\mathrm{CBFS}_{2}(7)$

Dari konstruksi $\mathrm{CBFS}_{2}(2 m+1)$, Bilotta memperoleh hasil berikut.

Teorema 2.3.1.1. $\operatorname{CBFS}_{2}(2 m+1)$ adalah kode cross bifix bebas dengan kardinalitas $C_{m}$ yang tak dapat diperluas di $H_{2}(2 m+1)$.

\subsubsection{Konstruksi $\mathrm{CBFS}_{2}(2 m+2)$ dengan $m$ genap}

Kode cross bifix bebas $\mathrm{CBFS}_{2}(2 m+2)$ untuk $m$ genap didefinisikan oleh Bilotta sebagai himpunan

$$
\operatorname{CBFS}_{2}(2 m+2)=\left\{\alpha x \beta \bar{x}: \alpha \in D_{2 i}, \alpha \in D_{2(m-i)}, 0 \leq i \leq \frac{m}{2}\right\},
$$

yaitu himpunan lintasan dengan panjang $2 m+2$ yang diawali dengan lintasan Dyck dengan panjang $2 i$, diikuti dengan langkah naik, lalu dilanjutkan dengan lintasan Dyck dengan panjang $2(m-i)$, kemudian diakhiri dengan langkah turun. Tentu saja, kardinalitas dari $\mathrm{CBFS}_{2}(2 m+2)$ untuk $m$ genap ini adalah $\sum_{i=0}^{\frac{m}{2}} C_{m} C_{m-i}$. Gambar 2.3.2.2 berikut memberikan gambaran bagaimana Konstruksi Bilotta menghasilkan kode $C_{B F}(6)$, yaitu himpunan kata/katakode $\{111000,110100,101100\}$. 


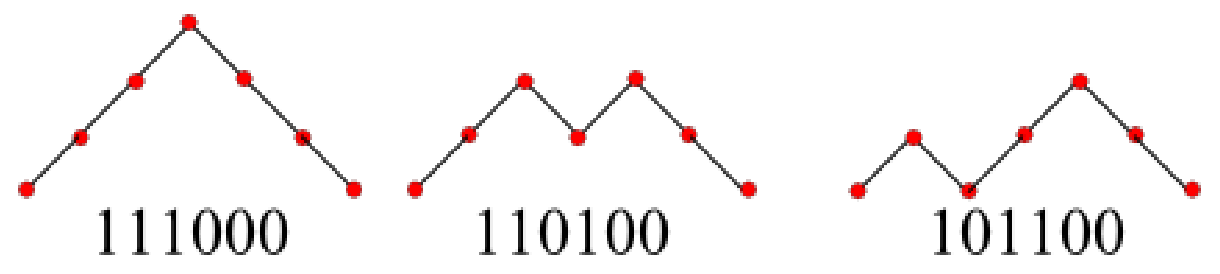

Gambar 2.3.2.1. Semua katakode di $C B F S_{2}(6)$

Dari konstruksi $\mathrm{CBFS}_{2}(2 m+2)$ untuk $m$ genap ini, Bilotta memperoleh hasil berikut.

Teorema 2.3.2.1. $\operatorname{CBFS}_{2}(2 m+2)$ untuk $m$ genap adalah kode cross bifix bebas dengan kardinalitas $\sum_{i=0}^{\frac{m}{2}} C_{i} C_{m-i}$ yang tak dapat diperluas di $H_{2}(2 m+2)$.

\subsubsection{Konstruksi $\mathrm{CBFS}_{2}(2 m+2)$ dengan $m$ ganjil}

Kode cross bifix bebas $\operatorname{CBFS}_{2}(2 m+2)$ untuk $m$ ganjil didefinisikan oleh Bilotta sebagai himpunan

$$
\begin{aligned}
\operatorname{CBFS}_{2}(2 m+2)= & \left\{\alpha x \beta \bar{x}: \alpha \in D_{2 i}, \alpha \in D_{2(m-i)}, 0 \leq i \leq \frac{m+1}{2}\right\} \\
& \backslash\left\{x a \bar{x} x \beta \bar{x}: \alpha \in D_{2 i}, \alpha \in D_{2(m-1)}\right\},
\end{aligned}
$$

yaitu himpunan lintasan dengan panjang $2 m+2$ yang diawali dengan lintasan Dyck dengan panjang $2 i$, diikuti dengan langkah naik, lalu dilanjutkan dengan lintasan Dyck dengan panjang $2(m-i)$, kemudian diakhiri dengan langkah turun; setelah semua lintasan ini terkumpul, maka Bilotta membuang semua lintasan yang diawali dengan langkah naik yang dilanjutkan dengan lintasan Dyck dengan panjang $m-1$, diikuti dengan langkah turun, lalu diikuti langkah naik, lalu dilanjutkan dengan lintasan Dyck dengan panjang $m-1$, kemudian diakhiri dengan langkah turun. Tentu saja, kardinalitas dari $\operatorname{CBFS}_{2}(2 m+2)$ untuk $m$ ganjil ini adalah $\sum_{i=0}^{\frac{m}{2}} C_{i} C_{m-i}-C_{\frac{m-1}{2}}^{2}$. Gambar 2.3.3.2 berikut memberikan gambaran bagaimana Konstruksi Bilotta menghasilkan kode $C B F S_{2}(8)$, yaitu $\{11110000,11011000,11100100,11101000,11010100,10111000\} \cup$ $\{10110100,10101100\}$. 


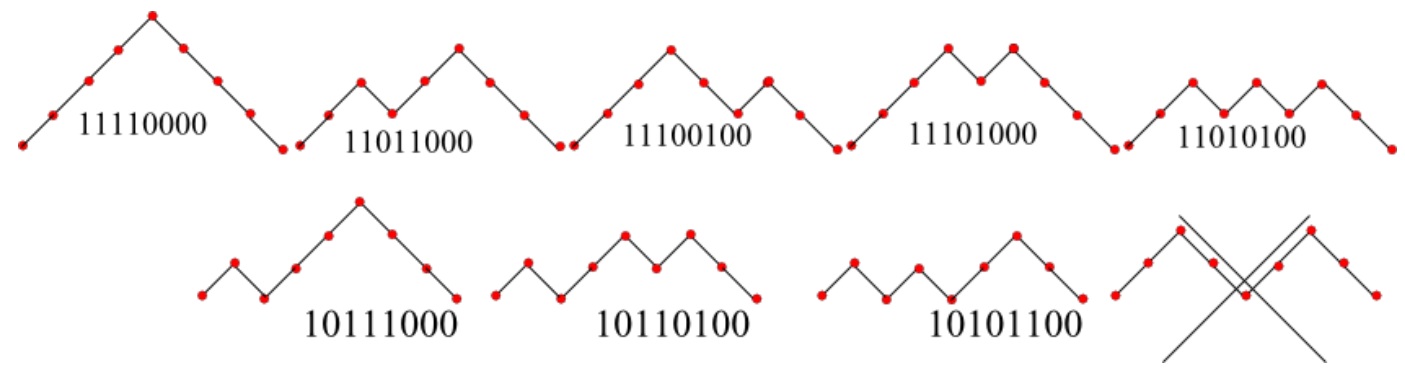

Gambar 2.3.3.1. Semua katakode di $C B F S_{2}(8)$

Dari konstruksi $\operatorname{CBFS}_{2}(2 m+2)$ untuk $m$ ganjil ini, Bilotta memperoleh hasil berikut.

Teorema 2.3.3.1. $\operatorname{CBFS}_{2}(2 m+2)$ untuk $m$ ganjil adalah kode cross bifix bebas berkardinalitas $\sum_{i=0}^{\frac{m+1}{2}} C_{i} C_{m-i}-C_{\frac{m-1}{2}}^{2}$ yang tak dapat diperluas di $H_{2}(2 m+2)$.

\subsection{Metode Konstruksi}

Berikut ini adalah metoda/konstruksi untuk memperluas konstruksi Bilotta untuk panjang genap ke Kode Cross Bifix Bebas ternair.

Konstruksi 2.4.1. Misalkan $\mathrm{CBFS}_{2}(2 m+2)$ adalah Kode Cross Bifix Bebas dengan panjang genap hasil konstruksi Bilotta. Perluasan $C_{B F S_{2}}(2 m+2)$ menjadiCBFS $S_{3}(2 m+2)$ adalah sebagai berikut.

i) Jadikan semua anggota $C_{B F S_{2}}(2 m+2)$ sebagai anggota $C B F S_{3}(2 m+2)$.

ii) Semua anggota $H_{3}(2 m+2)$ dari anggota $\operatorname{CBFS}_{2}(2 m+2)$ dengan cara mengganti 0 dengan 2, juga dijadikan anggota $C_{B F S_{3}}(2 m+2)$.

Seperti yang telah diketahui sebelumnya dari konstruksi Bilotta, CBFS $_{2}(5)=\{00011,00101\}$. Selanjutnya, semua kemungkinan mengganti simbol 0 pada 00011 dengan 2 adalah 00011; 20011; 02011; 00211; 22011; 20211; 02211; 22211 dan semua kemungkinan mengganti simbol 0 pada 00101 dengan 2 adalah 00101; 20101; 02101; 00121; 22101; 20121; 02121; 22121, sehingga diperoleh himpunancross bifix bebas ternair dengan panjang 5, CBFS $_{3}(5)=\{00011,20011,02011,00211,22011,20211,02211,22211\} \cup$ $\{00101,20101,02101,00121,22101,20121,02121,22121\}$.

Jika diperhatikan dengan seksama, semua anggota $C_{B F}(5)$ sama dengan 
barisan yang terbentuk dengan mengisi semua posisi 0 pada barisan di $\mathrm{CBFS}_{2}(5)$ dengan semua kemungkinan simbol genap di $\{0,1,2\}$.

\section{HASIL DAN PEMBAHASAN}

\subsection{Ide Konstruksi}

Dengan memperhatikan tinjauan pada bagian akhir subbagian sebelumnya, diperoleh Kontruksi 3.2.1 berikut yang selanjutnya akan diklaim sebagai hasilnya merupakan himpunan cross bifix bebas.

Konstruksi 3.1.1. Misalkan $\omega=\omega_{1} \omega_{2} \omega_{3} \ldots \omega_{2 m+2}$ anggota $\operatorname{CBFS}_{2}(2 m+2)$. Selanjutnya, definisikan $\mathbf{0}_{\omega}=\left\{i \in[n]: \omega_{i}=0\right\}$, yaitu himpunan semua posisi di $\omega$ yang bersimbol 0 . Himpunan $C_{B F S_{3}}(2 m+2)$ didefinisikan sebagai

$$
\operatorname{CBFS}_{3}(2 m+2)=\mathrm{U}_{\omega \in C B F S_{2}(n)} C_{\omega, 3}^{2 m+2}
$$

dimana

$$
C_{\omega, q}^{2 m+2}=\left\{c \in H_{3}(2 m+2): i \in \mathbf{0}_{\omega} \Rightarrow 2 \mid c_{i} ; \forall_{c_{i} \in\{0,1,2\}}\right\}
$$

yaitu himpunan barisan ternair yang posisi ke- $i$-nya bersimbol genap di $\{0,1,2\}$ jika posisi tersebut bersimbol 0 di $\omega$.

Sebagai contoh, jika ingin membentuk $\mathrm{CBFS}_{3}(4)$ maka cukup melihat $C B F S_{2}(4)$. Karena $C_{B F}(4)=\{1010,1100\}$, maka $\mathbf{0}_{1010}=\{2,4\}$ dan $\mathbf{0}_{1100}=\{3,4\}$. Sehingga didapat $\operatorname{CBFS}_{3}(4)=\{1010,1210,1012,1212,1100,1120,1102,1122\}$.

\subsection{Kode Cross Bifix Bebas $\mathrm{CBFS}_{3}(2 m+2)$}

Pada bagian ini, akan ditunjukkan bahwa himpunan $\operatorname{CBFS}_{3}(2 m+2)$ pada Konstruksi 3.2.1 tidak hanya himpunan barisan ternair hasil perluasan Konstruksi Bilotta, tetapi $\mathrm{CBFS}_{3}(2 m+2)$ juga merupakan Himpunan Cross Bifix Bebas. Hasil ini akan dibagi menjadi dua, yaitu untuk $m$ genap yang akan ditetapkan dalam Teorema 3.2.1 berikut dan untuk $m$ ganjil yang akan ditetapkan dalam Teorema 3.2.2.

Teorema 3.2.1. Untuk $m$ genap, $C B F S_{3}(2 m+2)$ adalah Kode Cross Bifix Bebas dengan kardinalitas $2^{m} \sum_{i=0}^{\frac{m}{2}} C_{m} C_{m-i}$.

Bukti. Dari konstruksi himpunan $\operatorname{CBFS}_{2}(2 m+2)$, untuk $m$ genap, diketahui 
bahwa untuk setiap $\omega$ di $\operatorname{CBFS}_{2}(2 m+2)$, berlaku $\mid$ pre $\left.e_{k} \omega\right|_{0} \geq \mid$ pre $\left.e_{k} \omega\right|_{1}$ dan $\left|s u f_{k} \gamma\right|_{0} \leq\left|s u f_{k} \gamma\right|_{1}$ untuk setiap $\omega$ dan $\gamma$ di $\operatorname{CBFS}_{2}(2 m+2)$ serta $0<k<$ $2 m+2$. Oleh karenanya, untuk setiap $w \in C_{\omega, q}^{2 m+2}$ dan $y \in C_{\gamma, q}^{2 m+2}$ berlaku

$$
\left|\operatorname{pre}_{k} w\right|_{0}+\left|\operatorname{pre}_{k} w\right|_{2} \geq\left|\operatorname{pre}_{k} w\right|_{1} \ldots(*)
$$

dan

$$
\left|s u f_{k} y\right|_{0}+\left|s u f_{k} y\right|_{2} \leq\left|s u f_{k} y\right|_{1} \ldots(* *)
$$

a) Untuk $\mid$ pre $\left.e_{k} \omega\right|_{0}>\mid$ pre $\left._{k} \omega\right|_{1}$, Karena $\operatorname{CBFS}_{2}(2 m+2)$ adalah himpunan lintasan latis yang diawali langkah naik yang diikuti lintasan Dyck dengan panjang $2 m$, maka untuk setiap $0<k<2 m+2$ berlaku $\mid$ pre $\left._{k} \omega\right|_{0}>$ $\mid$ pre $\left._{k} \omega\right|_{1}$ dan $\left|s u f_{k} \gamma\right|_{0} \leq\left|s u f_{k} \gamma\right|_{1}$ untuk setiap $\omega$ dan $\gamma$ anggota $\mathrm{CBFS}_{2}(2 m+2)$. Karena simbol genap pada barisan di $\operatorname{CBFS}_{3}(2 m+2)$ menempati posisi yang sama dengan posisi simbol 0 pada barisan di himpunan $\mathrm{CBFS}_{2}(2 m+2)$, maka untuk $k$ yang memenuhi kondisi $0<$ $k<2 m+2$, berlaku

$$
\left|\operatorname{pre}_{k} \alpha\right|_{0}+\left|\operatorname{pre}_{k} \alpha\right|_{2}>\left|\operatorname{pre}_{k} \alpha\right|_{1} \ldots(i)
$$

dan

$$
\left|s u f_{k} \beta\right|_{0}+\left|s u f_{k} \beta\right|_{2} \leq\left|s u f_{k} \beta\right|_{1} \ldots(i i)
$$

untuk setiap $\alpha$ dan $\beta$ di $\operatorname{CBFS}_{3}(2 m+1)$.

Sekarang, andaikan $\operatorname{CBFS}_{3}(2 m+2)$ bukan himpunan cross bifix bebas, maka ada $\bar{\alpha}$ dan $\bar{\beta}$ di $\operatorname{CBFS}_{3}(2 m+2)$ sehingga untuk suatu $k$ yang berada di $0<k<2 m+2$ berlaku $\operatorname{pre}_{k} \bar{\alpha}=s u f_{k} \bar{\beta}$. Akibatnya, berlaku $\left|\operatorname{pre}_{k} \bar{\alpha}\right|_{t}=\left|s u f_{k} \bar{\beta}\right|_{t}$ untuk setiap $t$ di [3].s Akibatnya, dengan menggunakan persamaan $(i)$, diperoleh

$$
\left|s u f_{k} \beta\right|_{0}+\left|s u f_{k} \beta\right|_{2}=\mid \text { pre }\left._{k} \alpha\right|_{0}+\mid \text { pre }\left._{k} \alpha\right|_{2}>\mid \text { pre }\left._{k} \alpha\right|_{1}=\left|s u f_{k} \beta\right|_{1}
$$

Namun, hal ini kontradiksi dengan persamaan (ii). Jadi $C_{\omega, q}^{2 m+2} \cup C_{\gamma, q}^{2 m+2}$ adalah himpunan cross bifix bebas.

b) Untuk $\mid$ pre $\left._{k} \omega\right|_{0}=\mid$ pre $\left._{k} \omega\right|_{1}$, Bilotta telah membuktikan bahwa untuk sebarang $\gamma$ di $\operatorname{CBFS}_{2}(2 m+2)$, berlaku $\left|s u f_{k} \gamma\right|_{0}<\left|s u f_{k} \gamma\right|_{1}$. Oleh karenanya, persamaan $(*)$ dan $(* *)$ menjadi

$$
\left|\operatorname{pre}_{k} w\right|_{0}+\left|\operatorname{pre}_{k} w\right|_{2}=\left|\operatorname{pre}_{k} w\right|_{1} \cdots(\bar{*})
$$


dan

$$
\left|s u f_{k} y\right|_{0}+\left|s u f_{k} y\right|_{2}<\left|s u f_{k} y\right|_{1} \cdots(\overline{* *})
$$

Sekarang, andaikan $C_{\omega, q}^{2 m+2} \cup C_{\gamma, q}^{2 m+2}$ bukan himpunan cross bifix bebas, maka ada $\bar{w}$ dan $\bar{y}$ di $C_{\omega, q}^{2 m+2} \cup C_{\gamma, q}^{2 m+2}$ sehingga untuk suatu $k$ yang berada di $0<k<n$ berlaku $\operatorname{pre}_{k} \bar{w}=\operatorname{suf}_{k} \bar{y}$. Akibatnya, berlaku $\left|\operatorname{pre}_{k} \bar{w}\right|_{t}=$ $\left|s u f_{k} \bar{y}\right|_{t}$ untuk setiap $t$ di $[q]$. Akibatnya, dengan menggunakan persamaan $(\bar{*})$, diperoleh

$\left|s u f_{k} \beta\right|_{0}+\left|s u f_{k} \beta\right|_{2}=\mid$ pre $\left._{k} \alpha\right|_{0}+\left|\operatorname{pre}_{k} \alpha\right|_{2}=\left|\operatorname{pre}_{k} \alpha\right|_{1}=\left|s u f_{k} \beta\right|_{1}$

Namun, hal ini kontradiksi dengan persamaan $(\overline{* *})$. Oleh karena itu, haruslah $C_{\omega, q}^{2 m+2} \cup C_{\gamma, q}^{2 m+2}$ adalah himpunan cross bifix bebas.

Jadi $\operatorname{CBFS}_{3}(2 m+2)=\cup_{\omega \in C B F S_{2}(2 m+2)} C_{\omega, 3}^{2 m+2}$ untuk $m$ genap adalah himpunan cross bifix bebas.

Terakhir, karena banyaknya cara mengganti simbol 0 sebanyak $t$ dengan simbol 2 pada setiap anggota $C_{B F S}(2 m+2)$ adalah sebanyak $\left(\begin{array}{c}m \\ t\end{array}\right)$ untuk setiap $t=$ $0,1,2,3, \ldots, m$ dan anggota $C B F S_{2}(2 m+2)$ untuk $m$ genap sebanyak $\sum_{i=0}^{\frac{m}{2}} C_{m} C_{m-i}$, maka diperoleh kardinalitas dari $\operatorname{CBFS}_{3}(2 m+2)$ untuk $m$ genap adalah

$$
\begin{aligned}
\left|\operatorname{CBFS}_{3}(2 m+2)\right| & =\underbrace{\left(\begin{array}{c}
m \\
m
\end{array}\right)+\cdots+\left(\begin{array}{c}
m \\
0
\end{array}\right)+\left(\begin{array}{c}
m \\
1
\end{array}\right)+\cdots+\left(\begin{array}{c}
m \\
m
\end{array}\right)}_{\left(\begin{array}{c}
m \\
0
\end{array}\right)+\left(\begin{array}{c}
m \\
1
\end{array}\right)+\cdots+\left(\begin{array}{c}
m \\
m
\end{array}\right) \operatorname{sebanyak} \sum_{i=0}^{\frac{m}{2}} C_{m} C_{m-i}} \\
& =\left[\left(\begin{array}{c}
m \\
0
\end{array}\right)+\left(\begin{array}{c}
m \\
1
\end{array}\right)+\left(\begin{array}{c}
m \\
2
\end{array}\right)+\left(\begin{array}{c}
m \\
3
\end{array}\right)+\cdots+\left(\begin{array}{c}
m \\
m
\end{array}\right)\right] \sum_{i=0}^{\frac{m}{2}} C_{m} C_{m-i} \\
& =2^{m} \sum_{i=0}^{\frac{m}{2}} C_{m} C_{m-i} .
\end{aligned}
$$

Teorema 3.2.2. Untuk $m$ genap, $C B F S_{3}(2 m+2)$ adalah Kode Cross Bifix Bebas dengan kardinalitas $2^{m}\left(\sum_{i=0}^{\frac{m}{2}} C_{i} C_{m-i}-\frac{C_{\frac{m-1}{2}}^{2}}{2}\right)$.

Bukti. Dari konstruksi himpunan $\mathrm{CBFS}_{2}(2 m+2)$, untuk $m$ ganjil, diketahui bahwa untuk setiap $\omega$ di $\operatorname{CBFS}_{2}(2 m+2)$, berlaku $\mid$ pre $\left.e_{k} \omega\right|_{0} \geq \mid$ pre $\left._{k} \omega\right|_{1}$ dan $\left|s u f_{k} \gamma\right|_{0} \leq\left|s u f_{k} \gamma\right|_{1}$ untuk setiap $\omega$ dan $\gamma$ di $C_{B F S}(2 m+2)$ serta $0<k<$ 
$2 m+2$. Oleh karena itu, seperti halnya bukti untuk $n=2 m+2$ dengan $m$ genap di atas, maka bukti untuk kasus ini cukup dibuktikan untuk kasus $\sum_{2 \mid t, t \in[q]} \mid$ pre $\left._{k} w\right|_{t}=\sum_{2 \nmid s, t \in[q]} \mid$ pre $\left.e_{k} w\right|_{s}$ untuk sebarang $w$ anggota $C_{\omega, q}^{2 m+2} \subseteq$ $\operatorname{CBFS}_{q}(2 m+2)$ dengan $\omega \in \operatorname{CBFS}_{2}(2 m+2)$ yang memenuhi $\mid$ pre $\left._{k} \omega\right|_{0}=$ $\mid$ pre $\left._{k} \omega\right|_{1}$ untuk sebarang $k$ di $0<k<2 m+2$.

a) Untuk $0 \leq i<\frac{m+1}{2}$ dan $1 \leq k \leq 2 i$, buktinya serupa dengan kasus untuk $n$ genap dengan $m$ genap

b) Untuk $i=\frac{m+1}{2}$ dan $1 \leq k<2 i$, buktinya juga serupa dengan kasus untuk $n$ genap dengan $m$ genap.

c) Untuk $i=\frac{m+1}{2}$ dan $k=2 i$

Perhatikan bahwa untuk kasus ini berlaku

$$
\left|\operatorname{pre}_{k} w\right|_{0}+\mid \text { pre }\left._{k} w\right|_{2}=\mid \text { pre }\left._{k} w\right|_{1}
$$

Andaikan $\operatorname{CBFS}_{3}(2 m+2)$ untuk $m$ genap bukan himpunan cross bifix bebas, maka terdapat $z \in C_{\gamma, 3}^{2 m+2} \subseteq C_{B F S_{3}}(2 m+2)$ sehingga berlaku $\operatorname{pre}_{k} w=\operatorname{suf}_{k} z$. Dari sini diperoleh $\operatorname{pre}_{u}\left(\operatorname{pre}_{k} w\right)=\operatorname{pre}_{u}\left(s u f_{k} z\right)$ untuk setiap $u$ yang memenuhi $0<u<k$. Hal ini mengakibatkan $\left|\operatorname{pre}_{u}\left(\operatorname{pre}_{k} w\right)\right|_{j}=\left|\operatorname{pre}_{u}\left(\operatorname{suf}_{k} z\right)\right|_{j}$ untuk setiap $j \operatorname{di}\{0,1,2\}$.

Sekarang, perhatikan bahwa $s u f_{k} \gamma=x \beta \bar{x}$, sehingga untuk setiap $k^{\prime}$ yang memenuhi $0<k^{\prime}<k$ berlaku

$$
\left|\operatorname{pre}_{k^{\prime}}\left(\operatorname{suf}_{k} z\right)\right|_{0}+\left|\operatorname{pre}_{k^{\prime}}\left(\operatorname{suf}_{k} z\right)\right|_{2}>\left|\operatorname{pre}_{k^{\prime}}\left(\operatorname{suf}_{k} z\right)\right|_{1} \ldots(\hat{\imath})
$$

Dilain pihak, karena $\operatorname{pre}_{k} \omega=\alpha \in D_{2\left(\frac{m+1}{2}\right)} \backslash\left\{x \bar{\alpha} \bar{x}: \bar{\alpha} \in D_{2\left(\frac{m-1}{2}\right)}\right\}$, maka terdapat bilangan asli $r$ yang kurang dari $k$ sehingga berlaku

$$
\left|\operatorname{pre}_{r}\left(\operatorname{pre}_{k} w\right)\right|_{0}+\left|\operatorname{pre}_{r}\left(\operatorname{pre}_{k} w\right)\right|_{2}=\left|\operatorname{pre}_{r}\left(\operatorname{pre}_{k} w\right)\right|_{1}
$$

Dari kesamaan ini, diperoleh

$\left|\operatorname{pre}_{k^{\prime}}\left(\operatorname{suf}_{k} z\right)\right|_{0}+\left|\operatorname{pre}_{k^{\prime}}\left(\operatorname{suf}_{k} z\right)\right|_{2}=\left|\operatorname{pre}_{r}\left(\operatorname{pre}_{k} w\right)\right|_{0}+\left|\operatorname{pre}_{r}\left(\operatorname{pre}_{k} w\right)\right|_{2}=$ $\left|\operatorname{pre}_{r}\left(\operatorname{pre}_{k} w\right)\right|_{1}=\left|\operatorname{pre}_{k^{\prime}}\left(\operatorname{suf}_{k} z\right)\right|_{1}$.

Jadi, terdapat bilangan asli $r$ yang memenuhi $0<r<k$ yang memenuhi

$$
\left|\operatorname{pre}_{k^{\prime}}\left(\operatorname{suf}_{k} z\right)\right|_{0}+\left|\operatorname{pre}_{k^{\prime}}\left(\operatorname{suf}_{k} z\right)\right|_{2}=\left|\operatorname{pre}_{k^{\prime}}\left(\operatorname{suf}_{k} z\right)\right|_{1}
$$

Hal ini kontradiksi dengan kesamaan $(\hat{\imath})$. Oleh karena itu, haruslah $C_{\omega, 3}^{2 m+2} \cup$ $C_{\gamma, 3}^{2 m+2}$ adalah himpunan cross bifix bebas. 
Jadi haruslah $\operatorname{CBFS}_{3}(2 m+2)=\mathrm{U}_{\omega \in C B F S_{2}(2 m+2)} C_{\omega, 3}^{2 m+2}$ untuk $m$ ganjil adalah himpunan/kode cross bifix bebas.

Terakhir, karena banyaknya cara mengganti simbol 0 sebanyak $t$ dengan simbol 2 pada setiap anggota $C_{B F S}(2 m+2)$ adalah sebanyak $\left(\begin{array}{c}m \\ t\end{array}\right)$ untuk setiap $t=$ $0,1,2,3, \ldots, m$ dan anggota $\operatorname{CBFS}_{2}(2 m+2)$ untuk $m$ ganjil sebanyak $\sum_{i=0}^{\frac{m}{2}} C_{i} C_{m-i}-C_{\frac{m-1}{2}}^{2}$, maka diperoleh kardinalitas dari $C_{B F S_{3}}(2 m+2)$ untuk $m$ ganjil adalah

$$
\begin{aligned}
\left|\operatorname{CBFS}_{3}(2 m+2)\right| & =\underbrace{}_{\left(\begin{array}{c}
m \\
0
\end{array}\right)+\left(\begin{array}{c}
m \\
1
\end{array}\right)+\cdots+\left(\begin{array}{c}
m \\
m
\end{array}\right)+\cdots+\left(\begin{array}{c}
m \\
0
\end{array}\right)+\left(\begin{array}{c}
m \\
1
\end{array}\right)+\cdots+\left(\begin{array}{c}
m \\
1
\end{array}\right)+\cdots+\left(\begin{array}{c}
m \\
m
\end{array}\right) \text { sebanyak } \sum_{i=0}^{\frac{m}{2}} C_{i} C_{m-i}-C_{\frac{m-1}{2}}^{2}} \\
& =\left[\left(\begin{array}{c}
m \\
0
\end{array}\right)+\left(\begin{array}{c}
m \\
1
\end{array}\right)+\left(\begin{array}{c}
m \\
2
\end{array}\right)+\cdots+\left(\begin{array}{c}
m \\
m
\end{array}\right)\right] \sum_{i=0}^{\frac{m}{2}} C_{i} C_{m-i}-C_{\frac{m-1}{2}}^{2} \\
& =2^{m}\left(\sum_{i=0}^{\frac{m}{2}} C_{i} C_{m-i}-C_{\frac{m-1}{2}}^{2}\right) .
\end{aligned}
$$

\section{SIMPULAN DAN SARAN}

Dari hasil penelitian ini, diperoleh kesimpulan bahwa Kode Cross Bifix Bebas hasil Konstruksi Bilotta untuk panjang genap, $C_{B F S_{2}}(2 m+2)$, dapat diperluas menjadi Kode Cross Bifix Bebas Ternair, $\operatorname{CBFS}_{3}(2 m+2)$. Langkah yang dilakukan adalah dengan cara mengganti semua posisi simbol 0 dengan semua kemungkinan simbol genap di [3]. Untuk penelitian selanjutnya, dapat dilakukan telaah apakah untuk sebarang panjang $n, C B F S_{3}(n)$ merupakan Kode Cross Bifix Bebas maksimal atau bukan. Artinya, untuk setiap $h$ di $H_{3}(n)$ yang tidak di $\mathrm{CBFS}_{3}(n)$, berlaku $\mathrm{CBFS}_{3}(n) \cup\{h\}$ bukan lagi kode cross bifix bebas.

\section{UCAPAN TERIMA KASIH}

Penulis mengucapkan syukur kepada Allah SWT, Alhamdulillaahi Robbil 'Aalamiiin. Selanjutnya, Penulis mengucapkan banyak terima kasih kepada DRPM KEMENRISTEK-DIKTI atas bantuan dana yang diberikan sehingga 
penulis dapat menyelesaikan penelitian ini dengan baik. Terakhir, Penulis juga mengucapkan banyak terima kasih kepada Bapak Aleams Barra Ph. D, Dosen FMIPA Matematika Institut Teknologi Bandung, atas arahan yang diberikan kepada penulis.

\section{DAFTAR RUJUKAN}

[1] Massey, James L.(1972). Optimum frame synchronization. Communications, IEEE Transactions on, 20(2):115

[2] Nielsen, P. T. (1973). On the expected duration of a search for a fixed pattern in random data. IEEE Transactions on Information Theory, 19(5):702

[3] Van Wijngaarden, A. D. L., \& Willink, T. J. (2000). Frame synchronization using distributed sequences. IEEE Transactions on Communications, 48(12), 2127-2138.

[4] Bajic, D., \& Stojanovic, J. (2004). Distributed sequences and search process. In IEEE International Conference on Communications.

[5] Bajic, D., Stefanovic, C., \& Vukobratovic, D. (2005, September). Search process and probabilistic bifix approach. In Information Theory, 2005. ISIT 2005. Proceedings. International Symposium on (pp. 19-22). IEEE.

[6] Bajic, D., \& Loncar-Turukalo, T. (2007). A simple suboptimal construction of cross-bifix-free codes. Cryptography and Communications, 6(1):27

[7] Bilotta, S., Pergola, E., \& Pinzani, R. (2012). A new approach to crossbifix-free sets. IEEE Transactions on Information Theory, 58(6), 40584063.

[8] Affaf, M., \& Ulum, Z. (2017, September 2). Konstruksi Kode Cross Bifix Bebas Ternair Untuk Panjang Ganjil. http://doi.org/10.17605/OSF.IO/KT27N

[9] Chee, Y. M., Kiah, H. M., Purkayastha, P., \& Wang, C. (2013). Crossbifix-free codes within a constant factor of optimality. IEEE Transactions on Information Theory, 59(7), 4668-4674.

[10] Blackburn, S. R. (2015). Non-overlapping codes. IEEE Transactions on Information Theory, 61(9), 4890-4894. 
[11] Emeric Deutsch. (1999). Dyck path enumeration. Discrete Mathematics,204(1):167

https://dx.doi.org/10.17605/OSF.IO/435GD 